Original article

\title{
Anabolic resistance assessed by oral stable isotope ingestion following bed rest in young and older adult volunteers: Relationships with changes in muscle mass
}

\author{
Gianni Biolo ${ }^{\text {a, * }}$, Rado Pišot ${ }^{\text {b }}$, Sara Mazzucco a , Filippo Giorgio Di Girolamo a, \\ Roberta Situlin ${ }^{\mathrm{a}}$, Stefano Lazzer ${ }^{\mathrm{c}}$, Bruno Grassi ${ }^{\mathrm{c}}$, Carlo Reggiani ${ }^{\mathrm{d}}$, Angelina Passaro ${ }^{\mathrm{e}}$, \\ Joern Rittweger ${ }^{\mathrm{f}}$, Mladen Gasparini ${ }^{g}$, Boštjan Šimunič ${ }^{\mathrm{b}}$, Marco Narici ${ }^{\mathrm{h}}$ \\ a Department of Medical, Surgical and Health Sciences, Clinica Medica AOUTS, University of Trieste, Italy \\ ${ }^{\mathrm{b}}$ Institute for Kinesiology Research, Science and Research Center of Koper, University of Primorska, Koper, Slovenia \\ ${ }^{c}$ Department of Medical and Biological Sciences, University of Udine, Udine, Italy \\ ${ }^{\mathrm{d}}$ Department of Biomedical Sciences, University of Padua, Padua, Italy \\ e Department of Medical Sciences, Section of Internal and Cardiorespiratory Medicine, University of Ferrara, Ferrara, Italy \\ ${ }^{\mathrm{f}}$ Institute of Aerospace Medicine, German Aerospace Center (DLR), Cologne, Germany \\ ${ }^{g}$ Department of Vascular Surgery, General Hospital Izola, Izola, Slovenia \\ ${ }^{\mathrm{h}}$ MRC/ARUK Centre for Musculoskeletal Ageing Research, University of Nottingham, Derby Royal Hospital, Derby, United Kingdom
}

\section{A R T I C L E I N F O}

\section{Article history:}

Received 15 June 2016

Accepted 22 September 2016

\section{Keywords:}

Anabolic resistance

Isotopic tracers

Skeletal muscle

Muscle atrophy

Bed rest

Aging

\begin{abstract}
S U M M A R Y
Background \& aims: Aging and experimental bed rest are associated with muscle atrophy and resistance to post-prandial stimulation of protein synthesis or anabolic resistance (AR). We have used in young and older adult volunteers, during short-term bed rest, a quick and non-invasive method, based on a single oral bolus of the stable isotope $\mathrm{L}\left[\mathrm{ring}-{ }^{2} \mathrm{H}_{5}\right]$ phenylalanine $\left(\mathrm{D}_{5} \mathrm{Phe}\right)$, to determine post-prandial AR, defined as ratio between irreversible hydroxylation and incorporation into body protein of ingested phenylalanine.

Methods: We compared in older $(0,59 \pm 1 \mathrm{y})$ and young $(\mathrm{Y}, 23 \pm 1 \mathrm{y})$ healthy male volunteers the effects of two-week bed rest on post-prandial protein kinetics, assessed during absorption of a standard readyto-use oral nutritional supplement, through stable-labeled isotope amino acid $\mathrm{D}_{5} \mathrm{Phe}$, diluted in water, given as single oral load. The metabolic fate of $\mathrm{D}_{5} \mathrm{Phe}$ is either utilization for protein synthesis or irreversible hydroxylation to $L\left[\right.$ ring- $\left._{-}^{2} \mathrm{H}_{4}\right]$ tyrosine $\left(\mathrm{D}_{4} \mathrm{Tyr}\right)$. AR was defined as ratio between the areas under the curves of $\mathrm{D}_{4}$ Tyr-to- $\mathrm{D}_{5}$ Phe plasma concentrations over $6 \mathrm{~h}$ meal absorption. To determine the relationships between AR and muscle changes following bed rest, quadriceps muscle volume (QMV) was determined by magnetic resonance imaging (MRI).

Results: At baseline, in pooled $\mathrm{Y}$ and $\mathrm{O}$ subjects, values of AR were inversely correlated with QMV $(\mathrm{R}=-0.75 ; \mathrm{p}<0.03)$. Following 2-weeks of inactivity, there were significant bed rest effects on AR $(\mathrm{p}<0.01)$ and QMV $(\mathrm{p}<0.03)$, as well as significant bed rest $\times$ group interaction for $\mathrm{AR}(\mathrm{p}<0.03 ;+9.2 \%$ in $\mathrm{Y} ;+21.9 \%$ in $\mathrm{O})$ and $\mathrm{QMV}(\mathrm{p}<0.05 ;-5.7 \%$ in $\mathrm{Y} ;-\% 7.3$ in $\mathrm{O})$. In pooled subjects, the percentage delta changes in AR and QMV, induced by bed rest, were inversely correlated $(R=-0.57 ; p<0.05)$.

Conclusion: Bed rest-induced AR is much greater in the older than in younger adults. We have developed a new, simple, non-invasive method for the assessment of AR. The results indicate that this metabolic abnormality is a key mechanism for sarcopenia of aging and inactivity.
\end{abstract}

() 2016 Elsevier Ltd and European Society for Clinical Nutrition and Metabolism. All rights reserved.
* Corresponding author. Clinica Medica, Cattinara Hospital, Strada di Fiume, 447 - 34149 Trieste, Italy. Tel.: +39 040399 4532; fax: +39040 3994593.

E-mail address: biolo@units.it (G. Biolo).

\section{Introduction}

Several physiological and pathological conditions are characterized by a reduced ability of meal proteins to stimulate postprandial protein synthesis. This metabolic alteration, defined as 


\begin{tabular}{|ll|}
\hline \multicolumn{2}{|l|}{ Abbreviations } \\
& \\
$\mathrm{O}$ & older \\
$\mathrm{Y}$ & young \\
$\mathrm{AR}$ & anabolic resistance \\
$\mathrm{D}_{5} \mathrm{Phe}$ & L[ring- $\left.{ }^{2} \mathrm{H}_{5}\right]$ phenylalanine \\
$\mathrm{D}_{4} \mathrm{Tyr}$ & L[ring- $\left.{ }^{2} \mathrm{H}_{4}\right]$ tyrosine \\
$\mathrm{QMV}$ & quadriceps muscle volume \\
$\mathrm{MRI}$ & magnetic resonance imaging \\
$\mathrm{AUC}$ & areas under the curves \\
$\mathrm{BMI}$ & body mass index \\
FM & fat mass \\
$\mathrm{Phe}$ & phenylalanine \\
Tyr & tyrosine \\
\hline
\end{tabular}

anabolic resistance, is evaluated through complex and invasive methodology based on intravenous infusion of stable isotopes of amino acids [1-4]. We, and others, have found that anabolic resistance (AR) is the key mechanism leading to muscle atrophy following prolonged physical inactivity $[2,3,5]$. These observations were obtained using the experimental bed rest model in young volunteers [5].

Evidence in healthy, active older subjects indicates that physiological aging is associated with AR [4]. Furthermore, aging is also characterized by sarcopenia [6]. These results support the latest recommendation for a higher protein requirement in older subjects in order to counteract AR and delay sarcopenia [7]. Nonetheless, the effects of experimental bed rest on the onset of AR in an aged population compared to young controls have never been investigated.

We recently completed a European funded project (PANGeA 2014, ClinicalTrials.gov Identifier: NCT02694471) to compare the response of skeletal muscle mass and function to a two-week period of bed rest in older adults and young men [8]. The results showed that the impact of inactivity on muscle was greater in the older than in the younger subjects. In the present study we propose a rapid and non-invasive method, tested within the frame of the two-weeks of bed-rest PANGeA 2014 study, based on a single oral bolus of the stable isotope $\mathrm{L}\left[\mathrm{ring}{ }_{-}^{2} \mathrm{H}_{5}\right.$ ]phenylalanine $\left(\mathrm{D}_{5} \mathrm{Phe}\right)$ to determine the AR to dietary protein stimuli for whole body protein synthesis. The metabolic fate of $\mathrm{D}_{5}$ Phe is either utilization for protein synthesis or irreversible hydroxylation to $\mathrm{L}\left[\mathrm{ring}-{ }^{2} \mathrm{H}_{4}\right]$ tyrosine ( $\mathrm{D}_{4} \mathrm{Tyr}$ ) [9]. In contrast to previous studies, which defined AR through assessment of post-prandial changes in endogenous protein kinetics, our new method defines AR as ratio between irreversible hydroxylation and incorporation into body proteins of ingested phenylalanine. Therefore, we defined AR as ratio between the areas under the curves (AUC) of $\mathrm{D}_{4}$ Tyr-to- $\mathrm{D}_{5}$ Phe plasma concentrations over 6 -h absorption of a standard ready-to-use oral nutritional supplement. To determine the relationships between $\mathrm{AR}$ and muscle changes following bed rest, quadriceps muscle volume (QMV) was determined by magnetic resonance imaging (MRI) in all subjects [8].

\section{Subjects and methods}

In the framework of the PANGeA project, eight healthy older adults (age, $59 \pm 1 \mathrm{y}$; body mass index, BMI, $27 \pm 1 \mathrm{~kg} / \mathrm{m}^{2}$ ) and seven young healthy adults (age, $23 \pm 1 \mathrm{y}$; BMI $24 \pm 1 \mathrm{~kg} / \mathrm{m}^{2}$ ) participated to 14-day experimental bed rest. The study was performed at the Orthopaedic Valdoltra Hospital, University of Primorska (Ankaran-Capodistria, Slovenia). The protocol was approved by the Ethic Committee of the University of Ljubljana
(Slovenia), and conformed to the standards set by the Declaration of Helsinki (2002) and its amendments. A written informed consent was obtained from each subject upon enrollment. Subjects were admitted at the hospital 3 days before bed rest in order to undergo basal measurements and get acquainted with the hospital environment (ambulatory period) and remained in the hospital for another 3 days (recovery phase) after the bed rest period. The whole study design is reported elsewhere [8]. Daily dietary intake was planned and monitored by an expert dietitian to maintain each subject in near-neutral eucaloric balance [10] and to provide a standard macronutrient intake, of around 60\% carbohydrate, 25\% fat, and $15 \%$ protein (about $1.0-1.1 \mathrm{~g} / \mathrm{kg} /$ day). In spite of the careful monitoring of food intake by the dietitian, one of the older subjects was excluded from the data analysis because of a severe negative energy balance (body mass loss of $4.5 \mathrm{~kg}$ ) developed during the bed rest period, since we have previously shown that a negative energy balance accelerates muscle loss during bed rest [3].

\subsection{Metabolic test}

Before the start (baseline) and at the last day of the bed rest protocol, we performed in each subject a metabolic test aimed at assessing the ratio between irreversible hydroxylation and incorporation into body protein of ingested phenylalanine, applying a new method based on bolus meal and oral stable isotope administration. The day of the study, at $7 \mathrm{AM}$, after an overnight fast, a polyethylene catheter was inserted into a forearm vein for blood collection. After a blood sampling, at time 0 , for baseline data, a liquid oral meal and an oral bolus of $\mathrm{D}_{5}$ Phe $(0.3 \mathrm{~g})$, dissolved in $150-200 \mathrm{~mL}$ of water, were administered to each subject to be consumed in $10 \mathrm{~min}$. The meal was a ready-to-use standard product (Nutricomp ${ }^{\circledR}$, B.Braun, $500 \mathrm{~mL}, 500 \mathrm{Kcal}$, vanilla flavor) composed by $15 \%$ protein (i.e., $18.75 \mathrm{~g}$ of proteins mainly derived from casein and soy), 30\% fat and 55\% carbohydrate. We have assessed in post-prandial conditions, changes in plasma $\mathrm{D}_{5} \mathrm{Phe}$ concentration, which is the net result of $D_{5}$ Phe absorption, utilization for protein synthesis and hydroxylation into $\mathrm{D}_{4} \mathrm{Tyr}$ (Fig. 1). The ratio between the AUC of both amino acids (i.e., AUC $\mathrm{D}_{4}$ Tyr-toAUC $D_{5}$ Phe ratio) expresses the amount of $D_{5}$ Phe, hydroxilated into $\mathrm{D}_{4}$ Tyr and not incorporated into body protein (Fig. 2A and B). Blood was collected in EDTA tubes, immediately centrifuged at $3000 \mathrm{~g}$ at $4{ }^{\circ} \mathrm{C}$ for $10 \mathrm{~min}$ and plasma was immediately stored at $-80^{\circ} \mathrm{C}$. In the same days, before the metabolic test, body fat mass has been assessed by bioimpedance analysis (BIA101, Akern, Florence, Italy), following manufacturer instructions, while muscle mass changes were assessed by continuous magnetic resonance images (MRI) (Magnetom Avanto; Siemens Medical Solution, Erlangen, Germany).

\subsubsection{Anabolic resistance: analysis and calculations}

Isotopic enrichments of plasma $\mathrm{D}_{5}$ Phe and $\mathrm{D}_{4} \mathrm{Tyr}$, derived by phenylalanine hydroxylation, were determined by gas chromatography-mass spectrometry (GC-MS) (HP 5890; Agilent Technologies, Santa Clara, CA) as t-butyldimethylsilyl derivatives [11]. Plasma concentrations of phenylalanine and tyrosine were assessed in all samples by GC-MS, using the internal standard technique, as previously described [11]. Known amounts of ${ }^{13} \mathrm{C}$ phenylalanine and ${ }^{2} \mathrm{H}_{2}$-tyrosine (Cambridge Isotope Laboratories, Andover, MA) were added as internal standards. Isotopic enrichments were assessed considering the following mass-tocharge ratios $\left(\mathrm{m} \times \mathrm{z}^{-1}\right)$ : phenylalanine $\mathrm{m} \times \mathrm{z}^{-1}$ 234-239; tyrosine $\mathrm{m} \times \mathrm{z}^{-1} 466-470$. Amino acid concentrations were assessed considering the following mass-to-charge ratios $\left(\mathrm{m} \times \mathrm{z}^{-1}\right)$ : phenylalanine $\mathrm{m} \times \mathrm{z}^{-1} 336-337$ and tyrosine $\mathrm{m} \times \mathrm{z}^{-1}$ 466-468. 


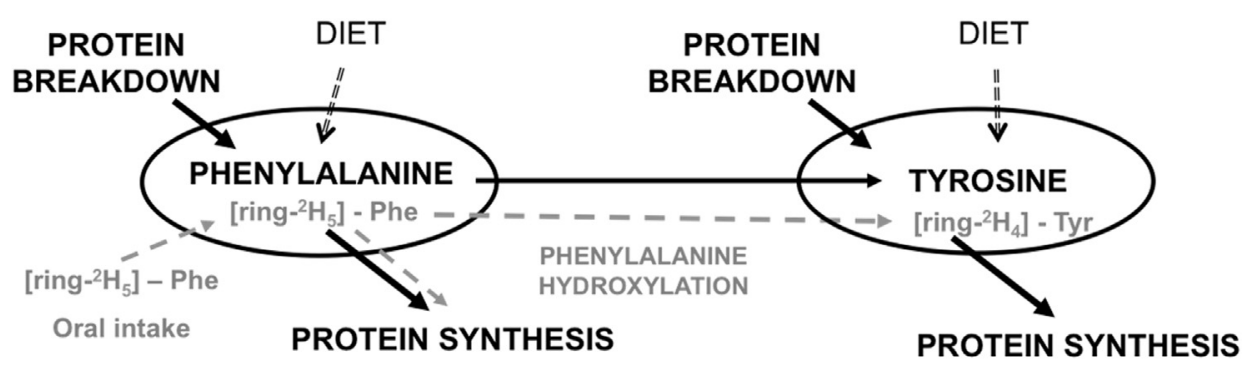

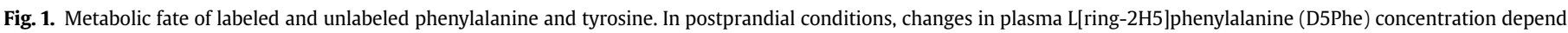

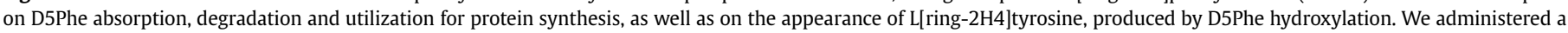
single oral bolus of D5Phe stable isotope to determine the anabolic resistance to dietary protein stimuli for whole body protein synthesis.

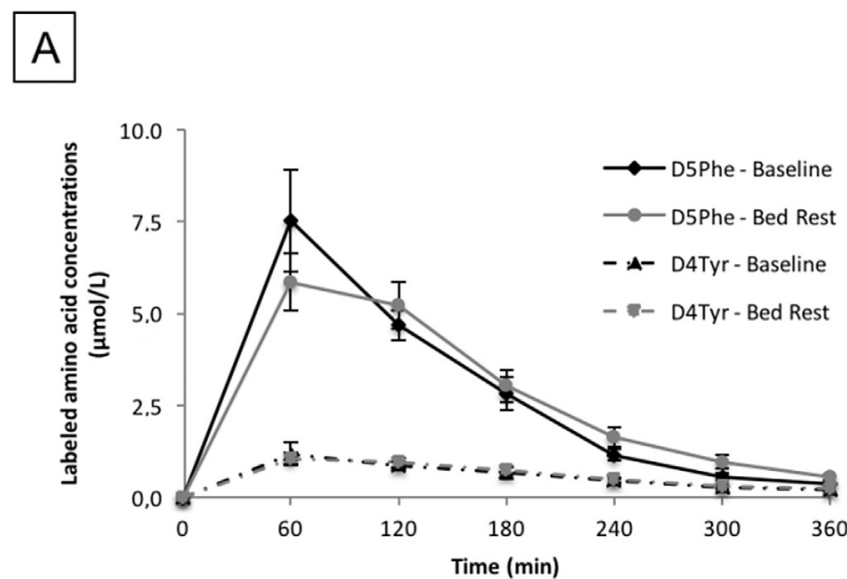

B

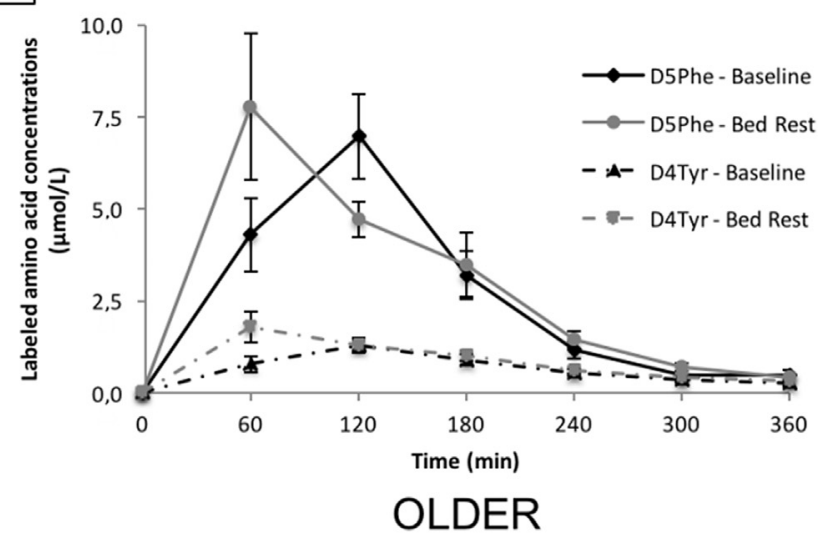

Fig. 2. Concentration-time curves of $\mathrm{D}_{5} \mathrm{Phe}$ and $\mathrm{D}_{4}$ Tyr plasma levels in young and older adults, before and after 14-d of bed rest. Plasma concentrations of D5Phe (continuous line) and D4Tyr (dotted line), after meal test, before (black) and at the end (grey) of 14-d bed rest, in healthy young (A) and older (B) adults. Values are expressed as mean \pm SEM. Time is given as minutes from the ingestion of the ready-to-use liquid oral meal plus the D5Phe oral bolus. D5Phe, L[ring-2H5]phenylalanine; D4Tyr, L[ring2H4]tyrosine.

Plasma concentrations of unlabeled amino acid [aa] were determined by the internal standard technique as follows:

[aa] $=a \times \mathrm{TTR}_{\mathrm{is}}$

where $a$ is the concentration of the internal standard added to plasma samples and $\mathrm{TTR}_{\mathrm{is}}$ is the isotopic enrichment of the internal standard.
$\mathrm{D}_{5}$ Phe and $\mathrm{D}_{4} \mathrm{Tyr}$ concentrations [aatracer] were calculated as follows:

$\left[\mathrm{aa}_{\text {tracer }}\right]=[\mathrm{aa}] \times \mathrm{TTR}_{\text {tracer }}$

where [aa] is plasma concentration of the tracee (unlabeled phenylalanine or tyrosine) and $\mathrm{TTR}_{\text {tracer }}$ is the isotopic enrichment of $\mathrm{D}_{5}$ Phe or $\mathrm{D}_{4} \mathrm{Ty}$.

The areas under plasma labeled amino acid concentrations versus time curves, were estimated using the linear trapezoidal method from time $0-6 \mathrm{~h}$. AR was defined as ratio between the areas under the curves of $\mathrm{D}_{4}$ Tyr-to- $\mathrm{D}_{5}$ Phe plasma concentrations over $6 \mathrm{~h}$ meal absorption, thereby expressing the fraction of $\mathrm{D}_{5} \mathrm{Phe}$, hydroxilated into $\mathrm{D}_{4} \mathrm{Tyr}$, not incorporated into body protein.

\subsubsection{Magnetic resonance images}

Quadriceps muscle volume of the dominant leg was measured by turbo spin-echo, T1-weighted, MRI obtained with 1.5 T (Magnetom Avanto; Siemens Medical Solution, Erlangen, Germany). On each MRI slice, contours corresponding to the quadriceps muscles were delineated by an MRI imaging expert, using the image processing tools OsiriX (Pixmeo Sarl, v.4.1.2). The muscle volume was then derived by summing a series of evenly spaced truncated cones, each encompassed between two axial images. The process included an average of 25 images (range 23-28) and covered the entire length of the quadriceps [8].

\subsection{Statistics}

Data were expressed as mean \pm SEM. Repeated measures ANOVA (or ANCOVA when appropriate) was applied to define the effects of bed rest and bed rest $\times$ group interaction on investigated parameters. Spearman's test was used to assess the correlations among changes in anabolic resistance and QMV in the two groups or changes between indices of anabolic resistance at different timing. Data were log-transformed where appropriate. $\mathrm{p}<0.05$ was considered statistically significant. Statistical analysis was performed using SPSS statistical software (v12; SPSS, Inc., Chicago, IL). Statistical significant main effects were confirmed at alpha 0.05 and interaction effect at alpha 0.10 .

\section{Results}

Table 1 shows the effects of bed rest on body mass, fat mass and quadriceps muscle volume in young and older adults. In basal conditions, muscle mass, expressed as quadriceps muscle volume (QMV) was significantly ( $\mathrm{p}=0.01$, unpaired t-test) greater in the young as compared to the older subjects. In contrast, body mass, fat mass and fat-free mass were not significantly different in the two groups. After two-weeks of experimental inactivity we observed a 
Table 1

Effect of 14-d bed rest on body mass and composition in young and older adults.

\begin{tabular}{|c|c|c|c|c|c|c|}
\hline & \multicolumn{2}{|c|}{ Young adults } & \multicolumn{2}{|c|}{ Older adults } & \multicolumn{2}{|l|}{ p-value ${ }^{a}$} \\
\hline & Basal & Bed rest & Basal & Bed rest & Bed rest effect & Bed rest $\times$ group interaction \\
\hline Weight (kg) & $74.8 \pm 3.3$ & $71.6 \pm 3.1$ & $79.6 \pm 3.7$ & $77.6 \pm 3.7$ & $<0.001$ & 0.07 \\
\hline FM (kg) & $14.0 \pm 2.3$ & $15.3 \pm 2.7$ & $19.9 \pm 1.7$ & $20.9 \pm 1.7$ & 0.64 & 0.66 \\
\hline FFM (kg) & $60.9 \pm 1.5$ & $56.3 \pm 1.4$ & $59.8 \pm 2.4$ & $56.7 \pm 2.4$ & $<0.001$ & 0.17 \\
\hline $\operatorname{QMV}\left(\mathrm{cm}^{3}\right)$ & $1987 \pm 100$ & $1896 \pm 78$ & $1660 \pm 41$ & $1538 \pm 37$ & $<0.03$ & $<0.05$ \\
\hline
\end{tabular}

Young adults, $\mathrm{N}=8$; older adults, $\mathrm{N}=7$. Data are expressed as mean $\pm \mathrm{SEM}$.

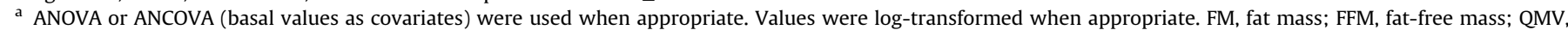
quadriceps muscle volume.

significant effect of bed rest on body mass and fat-free mass with no bed rest $\times$ group interaction. This effect determined a significant reduction of body mass in both groups. As expected, because of the maintained isocaloric condition, we did not observe any significant effect of bed rest or bed rest $\times$ group interaction on body fat mass (FM). QMV was significantly affected by 14 days of bed rest with a significant bed rest $\times$ group interaction $(-7.3 \pm 0.4 \%$ in older and $-5.7 \pm 1.5 \%$ in young). Individual values of FFM in young and older adults significantly $(\mathrm{p}<0.05)$ correlated with QMV in the basal ambulatory conditions $(\mathrm{R}=0.54)$, but not during bed rest $(\mathrm{R}=0.42)$.

Figure $2 \mathrm{~A}$ and $\mathrm{B}$ shows the values of fasting and post-prandial plasma concentrations of labeled $\left(\mathrm{D}_{5}\right.$ Phe and $\left.\mathrm{D}_{4} \mathrm{Tyr}\right)$, before (Baseline) and at the end of 14 days of bed rest in the young and older subjects. In the older volunteers, mean time to the point of maximum concentration of labeled amino acids tended to be delayed in the baseline condition as compared to the bed rest period. These differences, however, were not statistically significant.

At baseline, fasting plasma concentrations of phenylalanine and tyrosine were not significantly different in young $(65 \pm 5$ and $73 \pm 8 \mu \mathrm{mol} / \mathrm{L}$, respectively) and older subjects ( $54 \pm 4$ and $78 \pm 7 \mu \mathrm{mol} / \mathrm{L}$, respectively). We did not observe significant effects of bed rest on fasting plasma concentrations of phenylalanine and tyrosine in young and older subjects. There was not significant bed rest $\times$ group interaction for fasting plasma concentrations of phenylalanine and tyrosine. The AUC of plasma concentrations of labeled and unlabeled tyrosine and phenylalanine are reported in Table 2.

We did not observe either significant bed rest effect or a bed rest $\times$ group interaction on tyrosine AUC, however phenylalanine AUC was significantly affected by 14 days of bed rest in both groups with no significant bed rest $\times$ group interaction. We did not observe significant bed rest effect or bed rest $\times$ group interaction on AUC $D_{5}$ Phe, index of tracer absorption, whereas AUC $\mathrm{D}_{4} \mathrm{Tyr}$, derived from the hydroxylation of $\mathrm{D}_{5} \mathrm{Phe}$, was significantly affected by bed rest with a strong tendency on the bed rest $\times$ group interaction evidencing a greater increment of AUC $\mathrm{D}_{4}$ Tyr in the older $(+33 \pm 16 \%)$ volunteers than in the young $(+11 \pm 14 \%)$ subjects.

We have defined the ratio between the AUC of $\mathrm{D}_{4}$ Tyr and the AUC of $\mathrm{D}_{5}$ Phe as an index of anabolic resistance to ingested protein. The baseline ratio between the AUC of $\mathrm{D}_{4} \mathrm{Tyr}$ and the AUC of $\mathrm{D}_{5} \mathrm{Phe}$ was greater in the older $(0.23 \pm 0.01)$, as compared to the younger volunteers $(0.19 \pm 0.02)$, without achieving statistical significance (unpaired t-test, $\mathrm{p}=0.07$ ). After 14 days of experimental inactivity, we observed a significant bed rest effect on the anabolic resistance index in both groups (older: $0.28 \pm 0.02$; young: $0.20 \pm 0.01$ ) (Fig. 3), with a significant bed rest $\times$ group interaction. There was an increment of $22 \pm 6 \%$ and $9 \pm 7 \%$ in the older and young volunteers, respectively.

At baseline, individual values of anabolic resistance (i.e., AUC $\mathrm{D}_{4}$ Tyr-to-AUC $\mathrm{D}_{5}$ Phe ratio) and quadriceps muscle volume were inversely correlated in young and older subjects $(R=-0.56$, $\mathrm{p}<0.03$; Fig. 4). Following 14 days of bed rest, percentage changes from baseline of individual values of AR (i.e., AUC $D_{4}$ Tyr-to-AUC $\mathrm{D}_{5}$ Phe ratio) and quadriceps muscle volume were inversely correlated in young and older subjects $(\mathrm{R}=-0.75, \mathrm{p}<0.03$; Fig. 5).

In postprandial conditions, changes in plasma $\mathrm{L}\left[\mathrm{ring}-{ }^{2} \mathrm{H}_{5}\right]$ phenylalanine ( $\mathrm{D}_{5} \mathrm{Phe}$ ) concentration depend on $\mathrm{D}_{5}$ Phe absorption, degradation and utilization for protein synthesis, as well as on the appearance of $\mathrm{L}\left[\mathrm{ring}_{-}{ }^{2} \mathrm{H}_{4}\right]$ tyrosine, produced by $\mathrm{D}_{5}$ Phe hydroxylation. We administered a single oral bolus of $\mathrm{D}_{5}$ Phe stable isotope to determine the anabolic resistance to dietary protein stimuli for whole body protein synthesis.

Plasma concentrations of $\mathrm{D}_{5}$ Phe (continuous line) and $\mathrm{D}_{4} \mathrm{Tyr}$ (dotted line), after meal test, before (black) and at the end (grey) of 14-d bed rest, in healthy young (A) and older (B) adults. Values are expressed as mean \pm SEM. Time is given as minutes from the ingestion of the ready-to-use liquid oral meal plus the $\mathrm{D}_{5}$ Phe oral bolus. $\mathrm{D}_{5} \mathrm{Phe}, \mathrm{L}\left[\mathrm{ring}-{ }_{-}^{2} \mathrm{H}_{5}\right.$ ]phenylalanine; $\mathrm{D}_{4} \mathrm{Tyr}$, L[ring- $\left.{ }^{2} \mathrm{H}_{4}\right]$ tyrosine.

Variation of the index of anabolic resistance (AUC D 4 Tyr/AUC $\mathrm{D}_{5}$ Phe), before (baseline) and at the end of 14-d bed rest, in healthy young (black columns) and older (white columns) adults, as

Table 2

Effect of 14-d bed rest on protein metabolism in young and older adults.

\begin{tabular}{|c|c|c|c|c|c|}
\hline & \multirow[t]{2}{*}{ Group } & \multirow[t]{2}{*}{ Basal } & \multirow[t]{2}{*}{ Bed rest } & \multicolumn{2}{|l|}{ p-value ${ }^{a}$} \\
\hline & & & & Bed rest effect & Bed rest $\times$ group interaction \\
\hline \multirow[t]{2}{*}{ AUC Phe $(\mu \mathrm{mol} \times \mathrm{h} / \mathrm{L})$} & Young adults & $413 \pm 28$ & $430 \pm 19$ & 0.03 & 0.68 \\
\hline & Older adults & $401 \pm 12$ & $416 \pm 16$ & & \\
\hline \multirow[t]{2}{*}{ AUC Tyr $(\mu \mathrm{mol} \times \mathrm{h} / \mathrm{L})$} & Young adults & $516 \pm 59$ & $502 \pm 45$ & 0.34 & 0.23 \\
\hline & Older adults & $600 \pm 44$ & $615 \pm 52$ & & \\
\hline \multirow[t]{2}{*}{ AUC $D_{5}$ Phe $(\mu \mathrm{mol} \times \mathrm{h} / \mathrm{L})$} & Young adults & $16.7 \pm 1.6$ & $16.4 \pm 1.4$ & 0.21 & 0.60 \\
\hline & Older adults & $16.1 \pm 1.6$ & $18.0 \pm 2.3$ & & \\
\hline \multirow[t]{2}{*}{ AUC $D_{4} \operatorname{Tyr}(\mu \mathrm{mol} \times \mathrm{h} / \mathrm{L})$} & Young adults & $3.3 \pm 0.6$ & $3.3 \pm 0.4$ & $<0.01$ & 0.06 \\
\hline & Older adults & $3.8 \pm 0.4$ & $4.9 \pm 0.7$ & & \\
\hline
\end{tabular}

Young adults, $\mathrm{N}=8$; older adults, $\mathrm{N}=7$. Data are expressed as mean $\pm \mathrm{SEM}$.

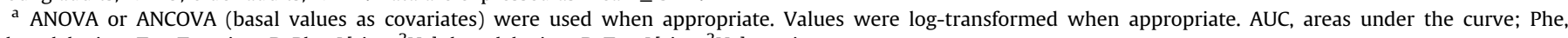
phenylalanine; Tyr, Tyrosine; $\mathrm{D}_{5} \mathrm{Phe}$, L[ring- ${ }^{2} \mathrm{H}_{5}$ ]phenylalanine; $\mathrm{D}_{4} \mathrm{Tyr}$, L[ring- $\left.{ }^{2} \mathrm{H}_{4}\right]$ tyrosine. 
ANCOVA

Bed rest effect $p<0.03$

Bed rest $\times$ group interaction $p<0.03$

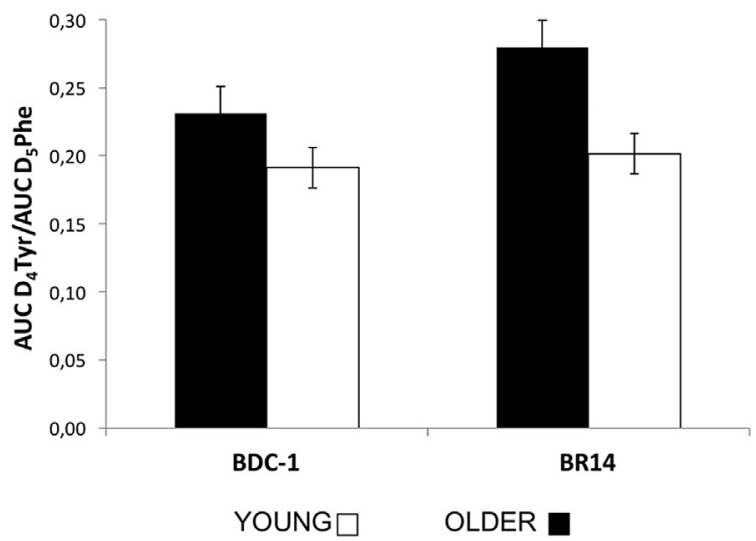

Fig. 3. Effect of 14-d bed rest on anabolic resistance of young and older adults. Variation of the index of anabolic resistance (AUC D4Tyr/AUC D5Phe), before (baseline) and at the end of 14-d bed rest, in healthy young (black columns) and older (white columns) adults, as assessed after 6-h meal test. Values are expressed as mean \pm SEM. ANCOVA analysis was performed using washout values as covariates. AUC, area under the curve; D5Phe, L[ring-2H5]phenylalanine; D4Tyr, L[ring-2H4]tyrosine.

assessed after 6-h meal test. Values are expressed as mean \pm SEM. ANCOVA analysis was performed using washout values as covariates. AUC, area under the curve; $\mathrm{D}_{5} \mathrm{Phe}, \mathrm{L}\left[\mathrm{ring}_{-}{ }^{2} \mathrm{H}_{5}\right]$ phenylalanine; $\mathrm{D}_{4}$ Tyr, $\mathrm{L}\left[\right.$ ring- $\left.{ }^{2} \mathrm{H}_{4}\right]$ tyrosine.

\section{Discussion}

Aging is associated with reduced whole-body and muscle protein synthesis after protein intake. This metabolic response, termed anabolic resistance contributes to sarcopenia [4,15]. In this study we assessed in young and older adults the effects of two weeks of experimental bed rest on the ability of a standardized meal to promote incorporation of dietary amino acids into body proteins. Changes in AR, defined as ratio between irreversible hydroxylation and incorporation into body proteins of ingested phenylalanine and quantified by a simple and non-invasive method based on stable isotope ingestion, were compared with effects of bed rest on muscle mass measured by MRI [8]. We found that bed rest

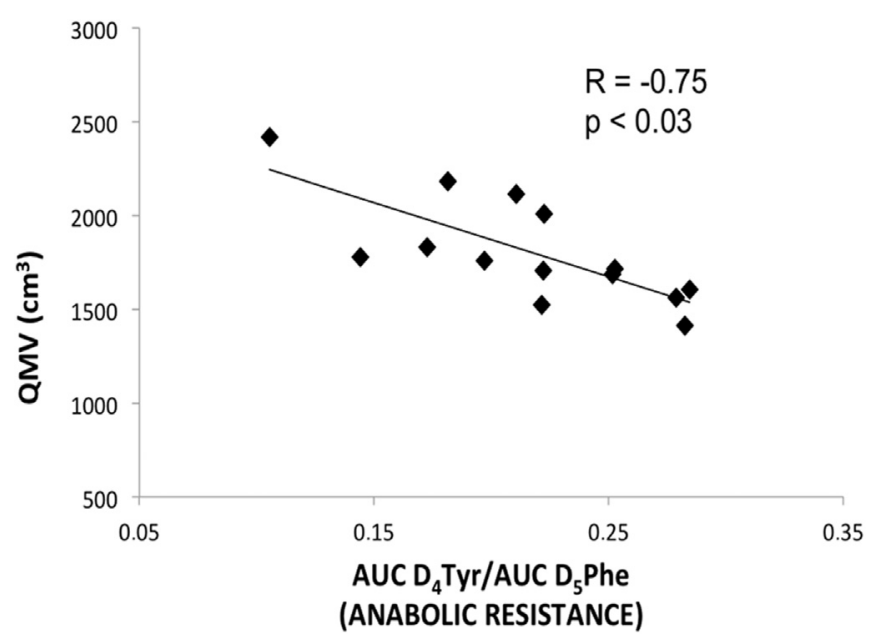

Fig. 4. Correlation between anabolic resistance and quadriceps muscle volume (QMV) in pooled young and older adults before 14 -d bed rest.

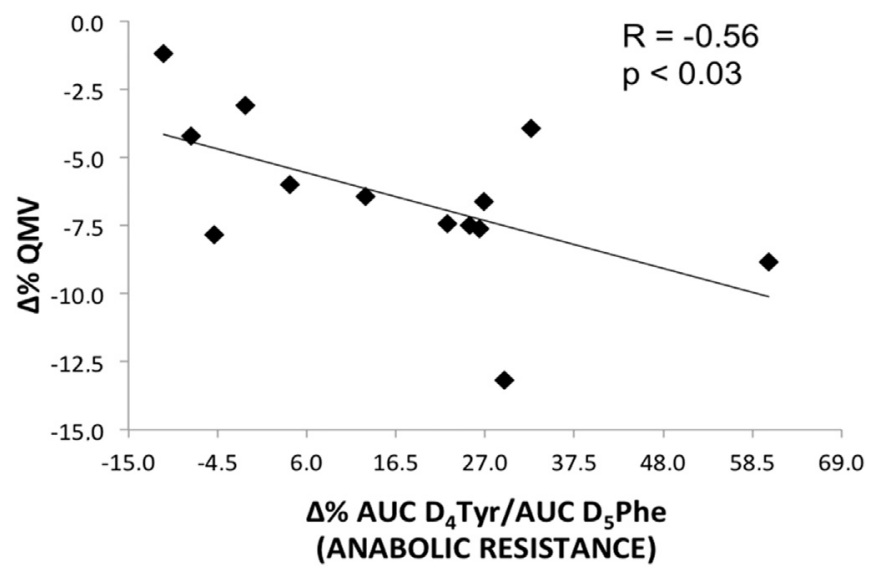

Fig. 5. Correlation between anabolic resistance and quadriceps muscle volume (QMV) as delta percentage changes, in pooled young and older adults after 14-d bed rest.

increased AR four-times more in the older than in the younger volunteers. Changes in AR inversely correlated with changes in muscle volume.

Table 3 reports selected studies describing the effects of inactivity and exercise on estimation of anabolic resistance in elderly and young subjects by different methods using stable isotopes $[1,2,4,13,16,17]$. Results and methods are compared with the present investigation.

The previous methodologies involved administration of stable isotopes of amino acids to follow their incorporation into body proteins. In order to apply traditional tracer dilution or incorporation equations, a metabolic steady-state is required, i.e., substrate concentrations in body fluids should not change over time. Thus, anabolic resistance has been often evaluated in non-physiological conditions, as during constant nutrient administration, either parenterally or enterally [1-4]. In addition, the assessment of AR in skeletal muscle requires multiple biopsies or vascular catheters, in femoral artery and vein, to measure fractional protein synthesis and monitor tracer disappearance into leg muscle protein, respectively $[4,12,16]$. At the whole-body level, two methods are currently available to determine the rates of amino acid utilization for protein synthesis in steady state condition. With the ${ }^{13} \mathrm{C}$-leucine method, irreversible amino acid oxidation is determined through the assessment of the ${ }^{13} \mathrm{CO}_{2}$ rate of appearance in the breath by indirect calorimetry combined with isotope-ratio mass-spectrometry [3]. The second method is based on continuous infusion of two independent tracers of phenylalanine and tyrosine. Irreversible phenylalanine hydroxylation is determined by monitoring transformation of labeled phenylalanine into the correspondent tyrosine tracer (e.g., $\mathrm{D}_{5}$-phenylalanine into $\mathrm{D}_{4}$-tyrosine) [9]. With both methods, the rate of amino acid incorporation into body protein is derived from the difference between rate of amino acid appearance and irreversible loss (e.g., oxidation for leucine or hydroxylation for phenylalanine). These methods require tracer infusions for several hours to achieve steady state conditions in both the postabsorptive and postprandial states.

Thus, several limitations are associated with current methodologies to assess AR in vivo, in humans. First, intravenous tracer infusion requires preparation of sterile and apyrogenic solutions. Second, application of steady state equations to determine protein synthesis requires intravenous tracer infusions for several hours and constant (non-physiological) nutrient administration to simulate experimental post-prandial state $[3,9,11]$. Third, muscle biopsies or femoral arterial and venous catheters are required to assess AR in muscle proteins $[4,12]$. 
Table 3

Effects of inactivity and exercise on estimation of anabolic resistance in elderly and young adults by different methods using stable isotopes.

\begin{tabular}{|c|c|c|c|c|}
\hline Reference & Methods & Experimental fed state & Conditions & Results \\
\hline Biolo et al., 2004 & $\begin{array}{l}\text { Whole-body protein synthesis, } \\
\text { degradation and balance by } \\
\text { constant infusion of } \mathrm{L}-\left[1-{ }^{13} \mathrm{C}\right] \\
\text { leucine }\end{array}$ & $\begin{array}{l}\text { Constant IV amino acid infusion } \\
(130 \mathrm{mg} / \mathrm{h} / \mathrm{kg} \mathrm{LBM})\end{array}$ & $\begin{array}{l}\text { Two weeks of experimental bed } \\
\text { rest in young subjects }\end{array}$ & $\begin{array}{l}\text { Net leucine deposition into body } \\
\text { protein was } \sim 8 \% \text { lower during bed } \\
\text { rest than during the ambulatory } \\
\text { phase }\end{array}$ \\
\hline Glover et al., 2008 & $\begin{array}{l}\text { Muscle myofibrillar fractional } \\
\text { synthetic rate by constant } \\
\left.\text { infusion of L-[ring- }{ }^{13} \mathrm{C}_{6}\right] \\
\text { phenylalanine }\end{array}$ & $\begin{array}{l}\text { Constant IV amino acid infusion } \\
\text { at low and high rates ( } 43 \text { and } \\
261 \mathrm{mg} / \mathrm{h} / \mathrm{kg} \text { ). }\end{array}$ & $\begin{array}{l}\text { Two weeks of unilateral leg } \\
\text { immobilization in young subjects }\end{array}$ & $\begin{array}{l}\text { Muscle myofibrillar fractional } \\
\text { synthetic rate in non- } \\
\text { immobilized leg was greater by } \\
\sim 54 \% \text { and } \sim 68 \% \text { with low and high } \\
\text { dose AA infusion, respectively. }\end{array}$ \\
\hline Biolo et al., 1997 & $\begin{array}{l}\text { Muscle fractional synthesis rate } \\
\text { and net leg muscle protein } \\
\text { balance by constant infusion of L- } \\
\text { [ring- }{ }^{13} \mathrm{C}_{6} \text { ]phenylalanine }\end{array}$ & $\begin{array}{l}\text { Constant IV amino acid infusion } \\
(150 \mathrm{mg} / \mathrm{h} / \mathrm{kg} \mathrm{LBM})\end{array}$ & $\begin{array}{l}\text { Young subject following } \\
\text { resistance exercise }\end{array}$ & $\begin{array}{l}\text { Muscle fractional synthesis rate } \\
\text { and net leg muscle protein } \\
\text { balance were } \sim 44 \% \text { and } \sim 120 \% \\
\text { greater after exercise than at rest, } \\
\text { respectively. }\end{array}$ \\
\hline Katsanos et al., 2005 & $\begin{array}{l}\text { Leg muscle arteriovenous } \\
\text { phenylalanine balance by } \\
\left.\text { constant infusion of L-[ring- }{ }^{2} \mathrm{H}_{5}\right] \\
\text { phenylalanine }\end{array}$ & $\begin{array}{l}\text { Bolus ingestion of } 15 \mathrm{~g} \text { essential } \\
\text { amino acids }\end{array}$ & $\begin{array}{l}\text { Elderly and young subjects in } \\
\text { ambulatory conditions }\end{array}$ & $\begin{array}{l}\text { Leg muscle protein balance was } \\
61 \% \text { lower in the elderly than in } \\
\text { the young adults. }\end{array}$ \\
\hline Durham et al., 2010 & $\begin{array}{l}\text { Fractional muscle protein } \\
\text { synthesis by primed continuous } \\
\left.\text { infusion of l-[ring- }{ }^{13} \mathrm{C}_{6}\right] \\
\text { phenylalanine }\end{array}$ & $\begin{array}{l}\text { Constant IV amino acid infusion } \\
(135 \mathrm{mg} / \mathrm{h} / \mathrm{kg})\end{array}$ & $\begin{array}{l}\text { Elderly and young subjects } \\
\text { following endurance exercise }\end{array}$ & $\begin{array}{l}\text { Efficiency of stimulation of } \\
\text { muscle protein synthesis was } \\
\text { reduced by } \sim 40 \% \text { in the elderly as } \\
\text { compared to the young adults. }\end{array}$ \\
\hline Present study & $\begin{array}{l}\text { Ratio between irreversible } \\
\text { hydroxylation and incorporation } \\
\text { into body protein of } \\
\text { phenylalanine ingested by bolus } \\
\text { oral administration of L- } \\
\text { [ring- }{ }^{2} \mathrm{H}_{5} \text { ]phenylalanine }\end{array}$ & $\begin{array}{l}\text { Bolus ingestion of mixed meal } \\
\text { (18.8 } \mathrm{g} \text { of protein) }\end{array}$ & $\begin{array}{l}\text { Two weeks of experimental bed } \\
\text { rest in young and older subjects }\end{array}$ & $\begin{array}{l}\text { The ratio between irreversible } \\
\text { hydroxylation and incorporation } \\
\text { into body protein of ingested } \\
\text { phenylalanine increased by } \sim 22 \% \\
\text { and } \sim 9 \% \text { following bed rest in the } \\
\text { elderly and young adults, } \\
\text { respectively. }\end{array}$ \\
\hline
\end{tabular}

In the present study, we have described a new methodology to assess AR in humans. An oral bolus of $\mathrm{D}_{5}$ Phe was administer in parallel with a standard ready-to-use oral nutritional supplement containing $500 \mathrm{kcal}, 15 \%$ protein, $30 \%$ fat and 55\% carbohydrate. Plasma concentrations of $\mathrm{D}_{5} \mathrm{Phe}$ and $\mathrm{D}_{4} \mathrm{Tyr}$ (derived from $\mathrm{D}_{5} \mathrm{Phe}$ through irreversible hydroxylation) were monitored for $6 \mathrm{~h}$ after meal ingestion. Tracer concentrations, calculated as tracer-totracee-ratio, multiplied by unlabeled amino acid concentration, were virtually zero after $6 \mathrm{~h}$ from meal ingestion. AUC of $\mathrm{D}_{5} \mathrm{Phe}$ and $\mathrm{D}_{4}$ Tyr concentrations were then calculated from time $0-6 \mathrm{~h}$. AR was defined as the ratio between the areas under the curves of $\mathrm{D}_{4}$ Tyr-to- $\mathrm{D}_{5}$ Phe plasma concentrations over 6-h meal absorption. This ratio expresses the fraction of ingested phenylalanine that is not utilized for body protein synthesis, i.e. AR. In fact, the only fate of phenylalanine is incorporation into protein synthesis or irreversible hydroxylation to tyrosine. The results are not affected by delay in enteral phenylalanine absorption, as long as the entire tracer AUC are monitored.

There are several advantages associated with our new method. First, tracers are administered orally and do not require sterility or apyrogenicity for intravenous infusions. Second, it does not require the use of infusion pumps for intravenous or enteral administration of tracers or substrates. Third, AR is investigated in a physiological postprandial state after administration of a standardized mixed meal.

This new methodology has some limitations, which have to be pointed out. First, only the metabolic fate of ingested phenylalanine (i.e., irreversible hydroxylation or incorporation into body proteins) has been traced by the oral isotope. Postprandial changes of synthesis and degradation of endogenous body proteins could not be assessed in our study. Constant intravenous isotope infusion and steady state conditions are required to trace endogenous body protein kinetics. Thus, the metabolic fate of administered dietary proteins/amino acids and endogenous protein kinetics cannot be simultaneously assessed during a physiological oral bolus meal. To overcome this methodological limitation, postprandial steady state conditions have been artificially created by constant oral (sip feeding) or intravenous nutrient administration. By these methods anabolic resistance has been demonstrated in bed resting young subjects and in ambulatory elderly. This experimental approach should be used in future studies to assess the response of endogenous protein kinetics to constant nutrient administration in young and elderly subjects in ambulatory conditions and during bed rest. Second, the ratio between irreversible hydroxylation and incorporation into body proteins can be affected by protein intake level. We could not perform multiple studies in our subjects to create a dose-response curve. Protein content of the isotope-enriched experimental meals (i.e., $18.75 \mathrm{~g}$ ) was equivalent to that provided in daily with each main meal (three main meals per day administered throughout the study). Total daily protein intake was within a narrow range in the young and older subjects (i.e., about $1.0-1.1 \mathrm{~g} / \mathrm{kg} / \mathrm{day}$ ) because body weight and fat-free mass were not significantly different in the two groups (Table 1). Third, the ability to utilize ingested amino acids for body protein synthesis can be affected by individual muscle mass. Sarcopenic conditions could be characterized by anabolic resistance simply because of reduced muscle mass. This mechanism may in part contribute to our results because bed rest induced muscle loss was greater in the older than in the young volunteers. We have normalized the amount of ingested protein utilized for body protein synthesis [i.e., $18.75 \mathrm{~g}$ multiplied by (1 - AUC D4Tyr/AUC D5Phe)] by kg of FFM in the young and older volunteers before and after bed rest. There was no significant effect of bed rest on this figure, however we found a significant bed rest $\times$ group interaction $(p=0.025$, ANCOVA). Therefore, the amount of ingested protein utilized for body protein synthesis normalized by FFM was $14 \%$ greater $(\mathrm{p}=0.03$, unpaired t-test with Bonferroni correction) in the young as compared to the older volunteers during bed rest. This value was not significantly different in the ambulatory condition. These results suggest that bed rest induced anabolic resistance directly contributed to the greater disuse atrophy observed in the quadriceps muscle of the elderly. In a previous 2week bed rest study in young subject, we have shown that the development of anabolic resistance preceded detectable changes in lean body mass as assessed by DEXA, thereby confirming our data [3]. 
In full agreement with previous studies $[2,3,13]$, we found an effect of bed rest on post-prandial AR in the two groups of young and older adults. However, the impact of unloading on AR was significantly greater in the older, as compared to the younger volunteers. These results suggest that older adults are more susceptible to the negative effects of unloading on postprandial protein anabolism, as compared to younger individuals.

Human studies clearly indicate that decreased protein synthesis in the postprandial state is the main protein catabolic mechanism associated with muscle unloading and aging $[2,14]$. Sarcopenia is defined as a progressive decline in skeletal muscle mass and function, strongly related to the decrease in autonomy and quality of life in the older population [6]. Inactivity is a key mechanism of sarcopenia of aging. In our study, the effects of bed rest in the young and in the older adults on skeletal muscle mass were assessed as quadriceps volume by MRI. As expected [18], bed rest significantly decreased QMV in both young and older adults, however percent decreases in muscle mass were greater in the old than in the young group. In pooled young and older subjects, changes induced by bed rest in AR and in QVM were inversely correlated (Fig. 5). In addition, at baseline, AR was inversely correlated with quadriceps muscle volume (Fig. 4). These results clearly suggest that AR is a key mechanism for sarcopenia of aging and inactivity.

We have previously shown that both underfeeding and overfeeding can accelerate muscle loss during physical inactivity $[3,10]$. In the present study, energy intake was carefully tailored to energy requirement of individual subjects and to the level of physical activity. Energy balance was maintained throughout the experimental periods as shown by the fact that fat mass of young and older adults were not modified during bed rest (Table 1 ). Thus, changes in AR or muscle mass were not affected by changes in energy balance.

In conclusions, we have developed a new, simple, non-invasive methodology to quantify AR in humans. Results suggest cause-effect relationships between inactivity-induced AR and muscle loss in both young and older subjects. AR is associated with increased protein requirement, as in the older and during inactivity [7]. Our new method allows to closely monitor changes in AR in different conditions.

\section{Funding}

The study was conducted in the framework of the project PANGeA: CB147 - Physical Activity and Nutrition for Quality Ageing, supported by the Cross-border Cooperation Program Slovenia-Italy 2007-2013.

\section{Authors' contributions to manuscript}

GB, designed research, analyzed data and performed statistical analysis, wrote paper and had primary responsibility for final content; RP, designed research, conducted research; SM, conducted research, analyzed data and performed statistical analysis; FGDG, conducted research, analyzed data and performed statistical analysis, wrote paper; RS conducted research, analyzed data and wrote paper; SL, conducted research; BG, designed research, conducted research; CR, designed research, conducted research; AP, designed research, conducted research; JR, designed research, conducted research; MG, conducted research; BS, designed research, analyzed data; MN, designed research, conducted research, analyzed data. All authors have read and approved the final manuscript. Additional contribution: we thank all participants of the study.

\section{Conflict of interest}

The authors declare no competing financial interest.

\section{Acknowledgments}

We would like to thank the participants in the study for their time and effort to ensure the success of the project. We acknowledge the excellent assistance of the entire staff of the Orthopaedic Hospital Valdoltra (Koper, Slovenia). Additionally, we thank Mrs. Mariella Sturma of the University of Trieste Research Laboratory, for excellent technical support, the research team and the students of Applied Kinesiology of University of Primorska for the help and logistic support and many other researchers and colleagues from different Institutes and different countries who contributed to the smooth undertaking of the study.

\section{References}

[1] Deutz NE, Wolfe RR. Is there a maximal anabolic response to protein intake with a meal? Clin Nutr 2013;32(2):309-13.

[2] Biolo G, Ciocchi B, Lebenstedt M, Barazzoni R, Zanetti M, Platen P, et al. Shortterm bed rest impairs amino acid-induced protein anabolism in humans. J Physiol 2004 Jul 15;558(Pt 2):381-8.

[3] Biolo G, Ciocchi B, Stulle M, Bosutti A, Barazzoni R, Zanetti M, et al. Calorie restriction accelerates the catabolism of lean body mass during $2 \mathrm{wk}$ of bed rest. Am J Clin Nutr 2007 Aug;86(2):366-72.

[4] Katsanos CS, Kobayashi H, Sheffield-Moore M, Aarsland A, Wolfe RR. Aging is associated with diminished accretion of muscle proteins after the ingestion of a small bolus of essential amino acids. Am J Clin Nutr 2005 Nov;82(5): 1065-73.

[5] Biolo G, Ciocchi B, Stulle M, Piccoli A, Lorenzon S, Dal Mas V, et al. Metabolic consequences of physical inactivity. J Ren Nutr 2005 Jan;15(1):49-53.

[6] Biolo G, Cederholm T, Muscaritoli M. Muscle contractile and metabolic dysfunction is a common feature of sarcopenia of aging and chronic diseases: from sarcopenic obesity to cachexia. Clin Nutr 2014 Oct;33(5):737-48. http:// dx.doi.org/10.1016/j.clnu.2014.03.007. Epub 2014 Mar 29.

[7] Deutz NE, Bauer JM, Barazzoni R, Biolo G, Boirie Y, Bosy-Westphal A, et al. Protein intake and exercise for optimal muscle function with aging: recommendations from the ESPEN Expert Group. Clin Nutr 2014 Dec;33(6):929-36. http://dx.doi.org/10.1016/j.clnu.2014.04.007. Epub 2014 Apr 24

[8] Pisot R, Marusic U, Biolo G, Mazzucco S, Lazzer S, Grassi B, et al. Greater loss in muscle mass and function but smaller metabolic alterations in older compared to younger men following two weeks of bed rest and recovery. J Appl Physiol (1985) 2016 Apr 15;120(8):922-9. http://dx.doi.org/10.1152/ japplphysiol.00858.2015.

[9] Matthews DE. An overview of phenylalanine and tyrosine kinetics in humans. J Nutr 2007 Jun;137(6 Suppl 1):1549S-55S. discussion 1573S-1575S.

[10] Biolo G, Agostini F, Simunic B, Sturma M, Torelli L, Preiser JC, et al. Positive energy balance is associated with accelerated muscle atrophy and increased erythrocyte glutathione turnover during 5 wk of bed rest. Am J Clin Nutr 2008;88:950-8.

[11] Antonione R, Caliandro E, Zorat F, Guarnieri G, Heer M, Biolo G. Whey protein ingestion enhances postprandial anabolism during short-term bed rest in young men. J Nutr 2008 Nov;138(11):2212-6.

[12] Bechshoeft R, Dideriksen KJ, Reitelseder S, Scheike T, Kjaer M, Holm L. The anabolic potential of dietary protein intake on skeletal muscle is prolonged by prior light-load exercise. Clin Nutr 2013 Apr;32(2):236-44. http://dx.doi.org/ 10.1016/j.clnu.2012.06.015.

[13] Glover EI, Phillips SM, Oates BR, Tang JE, Tarnopolsky MA, Selby A, et al. Immobilization induces anabolic resistance in human myofibrillar protein synthesis with low and high dose amino acid infusion. J Physiol 2008 Dec 15;586(Pt 24):6049-61. http://dx.doi.org/10.1113/jphysiol.2008.160333.

[14] Ferrando AA, Lane HW, Stuart CA, Davis-Street J, Wolfe RR. Prolonged bed rest decreases skeletal muscle and whole body protein synthesis. Am J Physiol 1996 Apr;270(4 Pt 1):E627-33.

[15] Cuthbertson D, Smith K, Babraj J, Leese G, Waddell T, Atherton P, et al. Anabolic signaling deficits underlie amino acid resistance of wasting, aging muscle. FASEB J 2005 Mar;19(3):422-4.

[16] Biolo G, Tipton KD, Klein S, Wolfe RR. An abundant supply of amino acids enhances the metabolic effect of exercise on muscle protein. Am J Physiol 1997 Jul;273(1 Pt 1):E122-9.

[17] Durham WJ, Casperson SL, Dillon EL, Keske MA, Paddon-Jones D, Sanford AP, et al. Age-related anabolic resistance after endurance-type exercise in healthy humans. FASEB J 2010 Oct:24(10):4117-27.

[18] Belavý DL, Miokovic T, Armbrecht G, Richardson CA, Rittweger J, Felsenberg D. Differential atrophy of the lower-limb musculature during prolonged bedrest. Eur J Appl Physiol 2009 Nov;107(4):489-99. 